\title{
Education and development projects in Brazil (1932-2004): Political economy perspective
}

\author{
BERNARDO STUHLBERGER WJUNISKI*
}

This paper discusses the long-run history of education policies in Brazil. It is suggested that the main reason for the educational backwardness was the existence of strong political interests over education. It is also defended that these interests can be empirically observed in the allocation of public resources between the different levels of education, with political choices favouring specific groups in society. It was not a matter of lack of investment in education, but of inadequate allocation of resources. This pattern of political-based policies created a strong negative path dependence of misallocation of resources in education in Brazil, particularly with significant underinvestment in secondary education.

Keywords: education; political interests; public expenditure.

JEL Classification: N36; O15.

\section{INTRODUCTION}

Speaking of education in the 1930s, the president of Brazil at that time, Getulio Vargas, said, "Education is a matter of life and death", and this statement was engraved in stone in the hall of the Ministry of Education in Rio de Janeiro (Havighurst \& Moreira, 1965, p. 132). However, during history, Brazilian education has always lagged behind other nations, even when compared to other developing economies. Brazilian educational indicators always presented some of the worst results compared to other Latin American countries, even the poorer ones (Frankema, 2008 p. 447; Boó, 2002, p. 255). On the other hand, during the twentieth century Brazil had some of the most significant positive rates of economic

\footnotetext{
* São Paulo School of Economics - Getulio Vargas Foundation (EESP-FGV). E-mail: bew@terra.com. br. Submetido: 23/dezembro/2010; Aprovado: 19/janeiro/2012.
} 
growth of the world (Abreu, 1990, pp. 398, 403, 408), particularly in the period 1930-1980. Table 1 reveals this paradoxical combination of high growth but poor educational performance.

Table 1: Literacy and GDP per capita growth — Latin America

\begin{tabular}{lcccccc}
\hline & \multicolumn{3}{c}{$\begin{array}{c}\text { Literacy } \\
\text { (percent) }\end{array}$} & \multicolumn{3}{c}{$\begin{array}{c}\text { GDP per capita growth } \\
\text { (percent per year) }\end{array}$} \\
\hline Country & 1900 & 1950 & 2000 & $1900-39$ & $1940-80$ & $1981-2000$ \\
Argentina & 51 & 88 & 97 & 1 & 1.7 & 0.6 \\
Brazil & 35 & 49 & 85 & 1.6 & 3.7 & 0.7 \\
Chile & 44 & 79 & 96 & 1.4 & 1.7 & 2.6 \\
Colombia & 34 & 62 & 92 & 0.3 & 2.1 & 0.7 \\
Mexico & 24 & 61 & 91 & 1 & 3.2 & 0.6 \\
Peru & 24 & 51 & 90 & - & - & - \\
Uruguay & 59 & 86 & 98 & - & - & - \\
Venezuela & 28 & 51 & 93 & 3.9 & 2.8 & -0.9 \\
\hline
\end{tabular}

Source: Bergés (2009, pp. 2, 3).

This backwardness continued until the present time. In the same period all other Latin American countries were catching-up with developed nations faster than Brazil in terms of educational development. The question that arises from this situation is straight-forward: What happened? Why has education in Brazil lagged behind?

While there is a vast body of literature discussing economic growth in Brazil, the literature that assesses this historical problem of education is still very incipient. In this sense, the objective of the paper is to contribute to this subject by providing new contributions to the topic. It will be suggested, similarly to the current literature, that education in Brazil always lagged behind because of policy decisions that were based on political reasons, with the existence of strong political interests over education. In addition, two contributions to the literature will be made. First, it will be argued that the political interests over educational policies can be seen in the light of the different development projects conducted by the distinct regimes. The role of education in each project reflected the political power of each time. Second, it will be suggested that these interests can be empirically observed in the allocation of public resources between the different levels of education, which reflects the political choices favouring specific groups in society. In this direction, it will be argued that the main reason for the backwardness was not a matter of lack of investment in education, but the allocation of resources based on political interests. The result of this situation was that these political-based policies created a strong negative path dependence of inadequate allocation of resources in the Brazilian educational system, particularly with significant underinvestment in secondary education.

The work is divided in three more sections. Second section briefly revises the literature that asses why education in Brazil has always lagged behind and dis- 
cusses the historical evolution of education policies in the country. The methodological approach will be of analysing the politics of education ${ }^{1}$, searching for the role of educational policies in each development project, and looking for the political interests behind each of them. After that, the third section presents the quantitative evidence that supports the argument. It analyses the evolution of long-run series (1933-2004) of enrolment and expenditure on the different levels of education, and also presents the results of a multiple structural break model that indicates the strong link between the expenditure structural breaks and the regime changes, supporting the political interests' hypothesis. Finally, fourth section concludes the paper with some possible future policy insights.

\section{THE POLITICAL ECONOMY OF EDUCATIONAL POLICIES IN BRAZIL}

\section{Why Education in Brazil lags behind?}

There is a growing debate in the Brazilian literature concerning how to improve the educational system (Menezes-Filho, 2007; Amaral \& Menezes-Filho, 2009). However, the existing literature that tackles the historical reasons for this situation is still very incipient, only a few studies try to answer the question of why education in Brazil has always lagged behind. While providing explanations from different perspectives, in general terms the literature agrees on the main reason for the backwardness of Brazilian education: political interests.

The general idea can be seen in the work of Peter Lindert. He argues that is possible to find in history many more cases of underinvestment than overinvestment in education. And, for at least three centuries, underinvestment in education has been the result of political decision-making, with political interests undermining the possibility of societies to fully invest in specific areas and levels of education (Lindert, 2009, p. 3). One of the authors that aggress with Lindert for the case of Brazil is David Plank. His general argument is that Brazil always had political systems that favoured private over public interests, resulting in non public-oriented policies (Plank et al., 1996, p. 120; Plank, 1996). Plank argues that throughout history all Brazilian governments were concerned with policies that favoured their own political base, which was normally the high elites of each period. As a result, policies focused on providing benefits only for these groups

Kang (2009) provides similar arguments to explain why Brazil did not develop its primary educational system during the period 1930-1964, a period during which its backwardness increased significantly. He argues that the existence of a high degree of political inequality, with political power concentrated in elites, which has

\footnotetext{
${ }^{1}$ This approach is based on Malloy (1979), which discuss the politics of social security in Brazil. His work provides a framework to analyse the relationship between the political environment and the economic outcomes in Brazil.
} 
its roots on the colonial times, undermined the possibilities of the expansion of primary education. Even with the expansion during this period of a middle class that demanded more schooling, this was not enough to make massive educational policies effective. Other similar answers are provided by Wegenast (2009a, 2009b) and Schwartzman (2004). In this sense, while answering from different perspectives, the literature in general argues that the main reason for the backwardness of the Brazilian education was political interests.

\section{From the Old Republic to Vargas Era}

The beginning of educational policies in Brazil started with the country's independence in 1822. However, until the end of the First Republic in 1930, it is not possible to discuss national educational policies. The beginning of federal and centralized policies occurred only with the passage from the Old Republic (1889-1930) to the Vargas Era (1930-1945) (Skidmore, 1967). The political structure of the First Republic (1889-1930) was mainly based on regionalism and local oligarchies. The formation of the Brazilian Federation with the Constitution of 1891 was a victory of the decentralized view. Due to this, the central government did not play an important role in many social and economic activities during this period. The states and their dominant agrarian oligarchies were fundamental in terms of political decisions (Fausto, 1994, p. 788; Bethell, 2008, p. 8). Educational policies were, during the entire First Republic, basically a state issue.

In terms of economic development, it was a period of growth of the primary exports strategy, which is described by the continuity of strong concentration of land and plantation-style production, similar to the system adopted during colonial times and the empire. All this period was characterized by the existence of strong relationships of clientelismo and also of significant political power from the agrarian oligarchies (Fausto, 1994, p. 809). The result of this process was a very diverse pattern of educational policies all around the country, and only in some urbanized and developed places some investment in education occurred, with benefits targeted to the elites. A clear example of this situation is that only a very small number of basic schools were set, normally in the state's capital, while many states started to build public universities for their elites. The beginning of the $20^{\text {th }}$ century was the time when this higher education system started to develop (Mendonça, 2000, p. 136).

This structure changed significantly with Getulio Vargas' government (1930-1945), not only in education but also in the whole political environment and development project of the country. Vargas led a project with the aim of building a centralized and for the first time fully national state, focusing on modernization, industrialization and growth (Skidmore, 1988). It was a period of significant investments in industrialization and the beginning of the import-substitution strategy in Brazil (Baer, 2003, pp. 55, 56). However, education was not a major part of the project at that time. In terms of political support, the Vargas government had to deal with two distinct forces to maintain its centralized power. First, it had to obtain the support of the new urban classes, which had been growing since the beginning 
of the industrialization. Second, Vargas had to negotiate the support of the agrarian elites, which continued in this period with their dominance over the political power in the countryside. In this sense, his policies had to focus on providing benefits for both groups (Bethell, 2008, pp. 19, 20). In relation to the urban sector, his modernizing project focused on providing them with industrial jobs and social security. This was their main demand. Regarding the agrarian elites, Vargas maintained their power, and so his policies had very little effect over the countryside. And as previously discussed, the agrarian elites were not interested in paying for schooling for their working class. As a result of this political structure, there was not much space and interest for implementing significant changes in educational policies. His modernizing project was targeted to the concerns of his political base (Bethell, 2008, p. 61).

However, some changes and improvements occurred in education. And it is possible to argue that this was the first positive step of educational policies in Brazil. Together with the administrative centralization of all social areas, education also became part of the scope of the central government, with the establishment of the Ministry of Education (Havighurst \& Moreira, 1965). Besides, the Constitution of 1934 (art. 5) established education as a free public good, also determining that a Law of education should be issued to regulate educational policies. These improvements were essentially related to the work of Gustavo Capanema, the Minister of Education between 1934 and 1945. With Capanema the bases of the Brazilian educational system started to develop, and a series of reforms in all educational levels took place, with the objective of transforming the different states systems into a uniform educational structure (Bomeny, 2008a). Capanema's reforms included a reformulation of the school curriculum, targeting the construction of a national identity, and giving a great deal of attention to Brazilian history, geography, literature and language. This was part of the project of building a modern and fully integrated national state (Bethell, 2008, p. 61).

Though, as already pointed out, besides Capanemas' interests, education was not a major part of the development project of Vargas in that period. The main focus of the modernizing plan was related to the economy. And a huge effort was made to modernize the production side by investing in the import substitution process (Baer, 2003, pp. 55, 56). As an example of the lack of importance given by the government to education it is possible to point to the fact that the interest in establishing a Law to regulate education was left aside, being brought back only in 1961.

\section{The Fourth Republic ${ }^{2}$ (1945-1964)}

After the end of the Vargas period, and its dictatorship with the Estado Novo (1937-1945), between 1945 and 1964 Brazil had a period of "open politics" between two dictatorships. Open in the sense that there was no full control of the

\footnotetext{
${ }^{2}$ Edgar Carone (1980) classifies this period as the Fourth Republic.
} 
political power by one person or group, and there was a reduced form of democracy in place (Bethel, 2008, p. 87) However, only a few could enter the political game, so it is not possible to talk about a complete democracy. In economic terms, it was a period of strong economic growth for the country, with full support of the government for the import-substitution strategy. However, until 1961, the development projects of the democratic presidents continued being very similar to the one of Vargas, focusing on industrialization and with little interest in educational policies (Skidmore, 1988). During this period, governments had many attitudes towards education, though just a few were really attempted. Already in 1948, the Minister of Education, Clemente Mariani, sent the first draft of the First Law of Direction and Bases for Education $\left(1^{\text {st }} \mathrm{LDB}^{3}\right)$ to the congress (Kang, 2009, p. 11). However, the Law was only approved in 1961.

One important president of that period was Juscelino Kubitschek (1956-1960). During his government, a large development plan was set out, the Plano de Metas, (Target Plan). This plan defined huge investments of the government and private sector in five prioritary areas: energy, transportation, basic industry, food and education (Silva, 2008). However, the educational sector was only given $3.4 \%$ of all investments of the program (Bomeny, 2008b, p. 1). As a result, while Brazil observed a strong development in many areas, education was left aside. The result of this lack of interest of the democratic governments was a strong increase of educational backwardness in Brazil.

Only in 1961, with the left wing President João Goulart, the first government with clear social policies, a significant changed occurred (Havighurst \& Moreira, 1965). João Goulart, who became president after the resign of Jânio Quadros, had a very different development project compared to the previous governments. With clear social interests, Goulart tried to start implementing new policies in Brazil. However, he stayed in government for just three years, the fear of socialism led to a military dictatorship in 1964 (Germano, 2000). However, even with such a small time in government, it was during his time that the First Law of Education $\left(1^{\text {st }} \mathrm{LDB}\right.$, 1961) was approved, just a few months after he arrived in power. The approval also reflected a movement of scholars and pedagogs who have been fighting for the LDB in the previous years, finding space for its approval during Goulart's administration (Havighurst \& Moreira, 1965). The LDB was the first clear regulatory framework of education in Brazil, and it was essentially based on the idea of education as an end in itself. Table 2 provides a comparison of the First Law of Education with the further ones that will be discussed later.

\footnotetext{
${ }^{3}$ Portuguese acronym for Lei de Diretizes e Bases para a Educação.
} 
Table 2: Brazilian Education Laws

\begin{tabular}{|c|c|c|c|c|}
\hline & $\begin{array}{c}\text { Expenditure } \\
\text { (Compulsory \%) }\end{array}$ & $\begin{array}{l}\text { Compulsory } \\
\text { Years of Study }\end{array}$ & $\begin{array}{c}\text { Compulsory } \\
\text { Annual Days } \\
\text { of Study }\end{array}$ & $\begin{array}{l}\text { Other Important } \\
\text { aspects }\end{array}$ \\
\hline $\begin{array}{c}1^{\text {st }} \text { Law - } \\
1961\end{array}$ & $\begin{array}{l}12 \% \text { federal, } 20 \% \text { sta- } \\
\text { tes and municipalities }\end{array}$ & $\begin{array}{l}\text { Primary } \\
\text { (7 - } 11 \text { years old) }\end{array}$ & 180 days & \\
\hline $\begin{array}{c}2^{\text {nd }} \text { Law - } \\
1971\end{array}$ & $\begin{array}{l}\text { No enforcement } \\
\text { on federal budget, } \\
20 \% \text { states and } \\
\text { municipalities }\end{array}$ & $\begin{array}{l}\text { Primary and } \\
\text { Secondary } \\
\text { ( } 7 \text { - } 14 \text { years old) }\end{array}$ & 180 days & $\begin{array}{l}\text { Free public secondary } \\
\text { education should be } \\
\text { gradually substituted } \\
\text { by loans for students. }\end{array}$ \\
\hline $\begin{array}{l}3^{\text {rd }} \text { Law - } \\
1996\end{array}$ & $\begin{array}{l}18 \% \text { federal, } 25 \% \text { sta- } \\
\text { tes and municipalities }\end{array}$ & $\begin{array}{l}\text { Primary and } \\
\text { Secondary } \\
\text { (7 - } 14 \text { years old) }\end{array}$ & $\begin{array}{l}200 \text { days }-800 \\
\text { hours }\end{array}$ & \\
\hline
\end{tabular}

Sources: Brazilian Educational Laws (1961, 1971 and 1996).

The most important aspects of the First Law were the enforcement of $12 \%$ of the federal budget and $20 \%$ of states and municipalities budget to be spend on education, and also the establishment of primary school as compulsory for all children in the country. The result of the First LDB was clear: an increase in expenditure in all levels of education, leading to a positive impact in enrolment rates, as it will be seen later in the data.

\section{The Military Dictatorship (1964-1984)}

The impacts of the first LDB were short. Just three years later, in 1964, Brazil entered a military dictatorship, and this generated another significant change in educational policies (Skidmore, 1988). During this period, and in contrast to the previous, the government started to see education as an important part of its development program, a big change compared to the previous governments. There were two main reasons why education had a new role in the development project. In first place, the militaries also had in their project the idea of continuing with industrialization and the import-substitution strategy, and this period (1968-1974) was a positive peak of this process, with the government inducing the country to achieve extremely high rates of economic growth - the so-called Economic Miracle (Milagre Econômico) (Hermann, 2005, p. 82). However, the militaries also defended improvements in human capital to allow a new step in productivity. Their strategy was to continue inducing growth by investing in a productive working class that could stimulate the country to continue growing. It was a view essentially related to the theoretical approach of education as a means to economic growth (Germano, 2000, p. 105).

Another important point that influenced educational policies at that time was 
the student's opposition. During the first years of dictatorship there was a huge increase in student protests, both with objective of showing opposition to the military government and also advocating more investment in education (Bethell, 2008, p. 184). In this direction, it is possible to say that educational policies during that time had two main objectives: modeling the student's view of the country, in order to protect the government against new opposition, and also investing in human capital to create a technical class that could guide the country to more growth. Due to these reasons education became more integrated into the development project.

The student protest and the interests of the new government in education as a means to economic growth led to two major reforms, of higher education in 1968 and of basic education in 1971, resulting in the establishment of the Second Law of Education in 1971 ( $2^{\text {nd }}$ LDB, 1971), during the presidency of Emílio Garrastazu Médici (Germano, 2000, p. 104). The Second LDB maintained some of the characteristics of the previous one, but also incorporated important changes. It preserved the budget requirement of $20 \%$ for states and municipalities, but left out any enforcement at the federal level, which could spend the sum it wanted on education. In addition, the most important aspect of the new legislation was the decision concerning secondary education, which was clearly left aside. The $2^{\text {nd }}$ LDB determined that secondary education should be withdrawn as a public good, being gradually replaced by loans for students:

"Art. 63. The gratuity of the public school and the scholarships offered by the Public Power will be progressively substituted, in secondary education, by the concession of loans subject to restitution" $\left(2^{\text {nd }} L D B\right.$, 1971, p. 11) ${ }^{4}$.

The quotation clearly indicates that not only was the government not interested in investing in secondary education, but it also had a clear plan of progressively withdrawing it as public good. It was a signal that secondary education was not part of the national project at that time. Investments in this level would go against the two roles of education in their development project. First, it would be contrary to the interests of targeting the policy towards the political base of the government: the rich classes that supported the regime and were able to obtain private secondary education and could consequently enter the higher level. And second, it would also be against their interests of reducing opposition. The militaries did not have any intention of providing the poor population with more schooling than the minimum qualification for a working class, afraid of the possibility of contestation of the regime. The year of 1968 was an example of the growing opposition to the regime, with a huge increase in protests both from workers and students (Bethell, 2005, p. 184). So the new Law also had the objective of reducing this resistance.

\footnotetext{
${ }^{4}$ Free translation from Portuguese.
} 
As a result of these interests, the practical results of the $2^{\text {nd }} \mathrm{LDB}$, which will be seen in the data, were: i) huge investments in higher education, with new universities and technical schools, targeting the desired skilled labour needed for growth; ii) new investments in primary education, to provide a minimum qualification standard for the poor population, and iii) a huge drop on secondary expenditure, as determine by the Law that secondary education should be gradually withdrawn as a public good.

As a consequence of these policies, a strong inequality between the levels of education in Brazil emerged, and the quality of secondary schooling declined significantly. A gap between classes was created, with basic schooling for the poor, and higher education for the rich. As will be clear from the quantitative data, the expenditure allocation of the government followed exactly this policy, with increases in primary and tertiary expenditure, and a huge reduction in secondary investments. The path dependency of this policy remains until today, with persistently bad quality secondary education, and a disproportional expenditure on higher education. The conditions for this path dependency will be deeply discussed later, but is important to stress that the meaning used here for this concept is of institutions which are self reinforcing. Once Brazil started this allocation of its public resources on education, there is a self reinforcing force within governments (political interests) which maintain this structure until today. As the data will show, despite some recent improvements Brazil still did not manage to fully correct this gap between levels.

\section{The Recent Democracy}

Even after the end of military rule, in 1985, educational policies remained based on the $2^{\text {nd }}$ LDB. In terms of economic development, the decades of $1980 \mathrm{~s}$ and 1990s did not follow the pattern that had been taking place since the 1930s. The country presented very low rates of economic growth, high external deficits and huge inflation. It is commonly argued that this situation was the result of a crisis of the import substitution strategy, with Brazil having exhausted all its substitution possibilities. It is also argued that one reason for the stagnation was the lack of technological learning during the substitution years. The copying process undermined the potential of the country to induce technological development by itself (Castro \& Tiezzi, 2004, pp. 144, 145). In this sense, it is interesting to notice that the stagnation that followed the substitution years was perhaps the result of an unsustainable type of growth, which was only based on the incorporation of capital. The lack of importance given to education during all the governments since the 1930s created a non-innovative labor market, which was not able to developed new technology and overcome the end of substitution possibilities. In this direction, the quality of Brazilian economic growth during the substitution years was low, resulting in a non-sustainable process in the future.

The situation of educational policies only changed with the Constitution of 1988 and the Third Law of Education (3 ${ }^{\text {rd }}$ LBD, 1996) in 1996. They came in a period with significant changes of economic policy in the country, which started to 
open its economy. The Constitution of 1988 already pointed out the new policies that were corroborated by the Law a few years later. They re-incorporated compulsory expenditure at the federal level, increasing it to $18 \%$, and also raised to $25 \%$ the compulsory expenditure of states and municipalities. Besides, the new Law clearly indicates a shift in expenditure towards primary and secondary education, the later being re-integrated as an important target for the governments. According to the study of Brown (2002, p. 117), these changes only became possible due to the advent of democracy and the reduction of the political power of the elites. He argues that the increase in electoral competition with the end of the military rule led to two main consequences: (i) an increase in the percentage of federal budget allocated to education; and (ii) a shift in spending from university to primary education.

These new policies are considered important steps in educational policies in Brazil, they are starting to reverse a long-run negative pattern of inadequate allocation of resources in education (Silva Junior \& Sguissardi, 2005, p. 23), which lasted for at least 28 years after the $2^{\text {nd }}$ LDB. With these measures, it can be said that education became, as in Goulart's years, an important social issue for the new democratic governments and also an end in itself, as demanded by society. In the recent years education remained a central part of the national project, but now with a totally different role in comparison to the military project (Dourado, 2002).

\section{ECONOMETRIC ANALYSIS}

In the previous section, it was argued that the main reason for the lagged situation was the existence of political interests over educational policies, with a strong relationship between the development projects of the regimes and their policy decisions. It was also argued that this situation can be seen in the light of the regimes' allocation of expenditure between the levels of education, with the adoption of political-based choices that favoured specific groups in society. This section will provide evidence for theses conclusion by analysing the long-run series of expenditure and enrolment in the different levels of education in Brazil, and also by performing a multiple structural break model over the series of expenditure. The basic idea of the model is to locate, without previous expectations on the data, structural breaks, and then relate them to the history of educational policies in Brazil discussed in the last section. The results indicate that the breaks in expenditure reflect extremely well the changes in the development projects, being directly linked to regime changes or new educational laws. These results support the argument presented in the previous discussion.

To start, before getting into the analysis of the allocation of expenditure between the levels of education, it is important to take a step back and show evidence that the overall level of expenditure in education in Brazil was not significantly different from other similar countries. This is necessary to support the argument that the main reason for the lagged situation was not the lack of investment, but the incorrect allocation of investment based on political interests. Table 3 provides 
this evidence, showing the overall expenditure of developing countries in education as a percentage of their current GDP since 1970, when this data becomes available.

Table 3: Overall Expenditure in Education — Developing Countries (\% of GDP)

\begin{tabular}{lcccccccc}
\hline Country & 1970 & 1975 & 1980 & 1985 & 1990 & 1995 & 2000 & 2005 \\
\hline Argentina & 1.5 & 1.8 & 2.6 & 1.4 & 3.3 & 3.6 & 4.6 & 3.8 \\
Brazil & 2.9 & 3.0 & 3.5 & 3.6 & 4.4 & 4.6 & 4.0 & 4.0 \\
Chile & 4.8 & 3.9 & 4.5 & 3.8 & 2.4 & 2.7 & 3.9 & 3.4 \\
South Korea & 3.5 & 2.1 & 3.5 & 4.2 & 3.3 & 3.2 & 4.3 & 4.6 \\
India & 2.4 & 2.3 & 2.9 & 3.2 & 3.7 & 3.3 & 4.4 & 3.2 \\
\hline
\end{tabular}

Source: UNESCO - Institute for Statistics.

The table indicates that Brazilian expenditure was not very different from other Latin American countries that achieved much better results in education, such as Chile and Argentina. It also shows a not very distinct pattern in comparison to South Korea, a country that is considered an example of investment in education in the post-WW2 period. This indicates that the lagged educational situation seems not to be a result of lack of investment, and consequently it would be better to analyse the allocation of expenditure within the education sector as a possible cause for the backwardness.

\section{Data}

The data used to perform the multiple structural break model comprise full series of total public expenditure (as percentage of the GDP) in the different educational levels for the period 1933-2004. The data includes all public expenses with education at the three levels of management: federal, states and municipalities. It does not include any private investment in education. The dataset also includes information on enrolment (as a percentage of the cohort of students in the age of each level) for the same period, which is useful to analyse the impacts of the different policies. The data ${ }^{5}$ was organized following the methodology proposed by Maduro (2007). Enrolment is calculated by dividing the number of enrolled students in each level by the cohort of the population in age of studying at that level. The cohorts are (i) Primary: 7-14 years old, (ii) Secondary: 15-17 years old, and (iii) Tertiary: 18-22 years old. Expenditure is calculated by dividing total expenditure in each level of education by the GDP. Linear interpolations were used to fill the gaps in the data. The evolution of enrolment and expenditure separately for each

\footnotetext{
${ }^{5}$ The data of enrolled students for the period 1933-1998 comes from the Anuários Estatísticos of IBGE (Instituto Brasileiro de Geografia e Estatística), organized and available at the Estatísticas do Século XX (CD-ROM), and for the period 1998-2008 from INEP (Instituto Nacional de Estudos e Pesquisas Educacionais), available on the INEP website. The population data for the whole period comes from IBGE. For expenditure on education and GDP, the data also comes from the Anuários Estatísticos of IBGE for the period 1933-1994, and from INEP for the period 1994-2004.
} 
of the three levels are presented in Graphs 1 to 3, which also include the results of the econometric test performed in the next sub-section.

The graphs reflect quite well the narrative of the history of educational policies described in the previous section. In terms of expenditure, it is possible to see the low stage at all levels of education until the First Law in 1961, with slight increases during the Vargas years. In 1971, it is possible to see the increase in expenditure of primary and tertiary educational, while secondary expenditure dropped. Finally, after the end of the dictatorship and the $3^{\text {rd }}$ Law of Education, there is the expected increase in educational expenditure in all levels. The enrolment data show the result of these policies. In primary education, we notice a linear growth in the rates of enrolment due to the long-run increase in expenditure. In the case of secondary education, there was a slow growth in enrolment after the policies of 1971, and a return to expansion after the third Law. Finally, in the higher education there is also a long-run increase in enrolment, which is stronger during the military years.

\section{Econometric Methodology}

The econometric technique adopted to identify multiple structural breaks in the series is based on the procedure proposed by Bai and Perron $(1998,2003)$. Formally, a test is perfomed to simultaneously locate multiple structural breaks and check their statistical significance, without imposing any prior expectations on the data, treating the numbers of breaks as an endogenous test parameter. This is the essential difference from this approach to the traditional ones, such as the Chow test, which test the presence of a structural break in a point pre-determined exogenously (Greene, 2008, p. 120; Enders, 2004, p. 202). The procedure estimates unknown regression coefficients together with the break points when $T$ years are available. The number of breaks, $m$, is then treated as unknown and it is necessary to fix a minimum interval length allowed between breaks. Note that there is an implicit trade-off involved: very short intervals risk resulting in very short-term shifts, whereas long intervals risk missing important break points. In order to define the best number of breaks, it is necessary to use some information criteria.

The procedure estimates a linear equation in the form:

$$
\begin{aligned}
& y_{t}=\mathrm{z}_{t}^{\prime} \delta_{t}+\mu_{t} \\
& t=T_{j-1}+1, \ldots, T_{j}, \text { for } j=1, \ldots, m+1,
\end{aligned}
$$

Where $T_{0}=0, T_{m+1}=T, y_{t}$ is the expenditure in education, $z_{t}$ is a dummy variable whose slope is $\delta$, and $\mu_{t}$ is the error term (Bai and Perron, 1998, p. 49). The procedure provides consistent estimates of the number of break points, the break point dates and the coefficients for each break.

The minimum interval fixed was of $10 \%$ of the series, 7.2 years, and the test was performed for a maximum of five break points. In order to define the number of break points, two information criteria will be used: the Bayesian Information Criterion (BIC), and the LWZ (Schwartz criteria) criterion, which are well-known and do not need to be discussed. 
After the structural breaks are located, it will be check if they are related to changes in the political environment of the country. If the breaks reflect the political movement, it is an indication that the real education policies - the observed expenditure in education - are truly related to the government policies and their development projects, suggesting that the proposed influence of political interests over educational policies was correct. It will also be possible to see the direction of the breaks, testing if the regimes favoured specific groups of society by increasing the expenditure in specific levels and decreasing in others.

\section{Results}

In all of the three exercises, BIC and LWZ indicated the same number of breaks, suggesting robust results. The number of breaks and their position in each level of education is presented in table 4 .

Table 4: Results of Structural Breaks Test

\begin{tabular}{lccc}
\hline & Primary & Secondary & Tertiary \\
\hline Number of Breaks & 3 & 4 & 3 \\
$1^{\text {st }}$ Break & 1963 & 1947 & 1951 \\
$2^{\text {nd }}$ Break & 1970 & 1963 & 1964 \\
$3^{\text {rd }}$ Break & 1985 & 1971 & 1986 \\
$4^{\text {th }}$ Break & & 1996 & \\
\hline
\end{tabular}

According to the results, primary and tertiary education have three structural break points, while secondary has four. Table 5 provides the analysis of the relationship of the structural breaks with the political environment of the country. It is possible to aggregate the break points into five groups. The first one is related to the end of Vargas period in the late 1940s. The second is related to the First Law of Education in the beginning of the 1960s. The third group is linked to the Second Law of Education in 1971. The fourth group is related to the end of the military dictatorship. And finally the last group is connected with the Third Law of Education in 1996. All the structural break points suggested by the tests are included in one of these moments of political change in Brazil, or directly linked to a change in political power or related to new political interests with the advent of educational laws.

Table 5: Political Relationship of Structural Breaks

\begin{tabular}{ccc}
\hline BreakYears & Levels of Education & Political Enviroment \\
\hline $1947-1951$ & Secondary \& Tertiiary & Return to Democracy \\
$1963-1964$ & Primary \& Tertiary & First Law of Education \\
1971 & Primary \& Secondary & Second Law of Education \\
$1985-1986$ & Primary \& Tertiary & End of Military Dictatorship \\
1996 & Secondary & Third Law of Education \\
\hline
\end{tabular}


An interesting first observation regarding the results of the structural breaks is the evident relationship between the break points of primary and tertiary education, which are different from the structural breaks observed in secondary education. As previously discussed, the reason for this situation is that governments usually invested in primary and higher education, with the increase in expenditure in these levels occurring in similar periods, during the First Law of Education and after the end of military dictatorship and the Constitution of 1989. On the other hand, secondary education was left aside, with the decrease in expenditure with the break point of 1971 and the military policy. It only recovered in 1996 after the Third Law of Education. A more clear understanding of the results can be seen through the analysis of graphs, which will elucidate these points. They indicate not only the break years but also their level, which was estimated by the coefficients of the model.

\section{Graph 1: Structural Breaks: Primary Education}

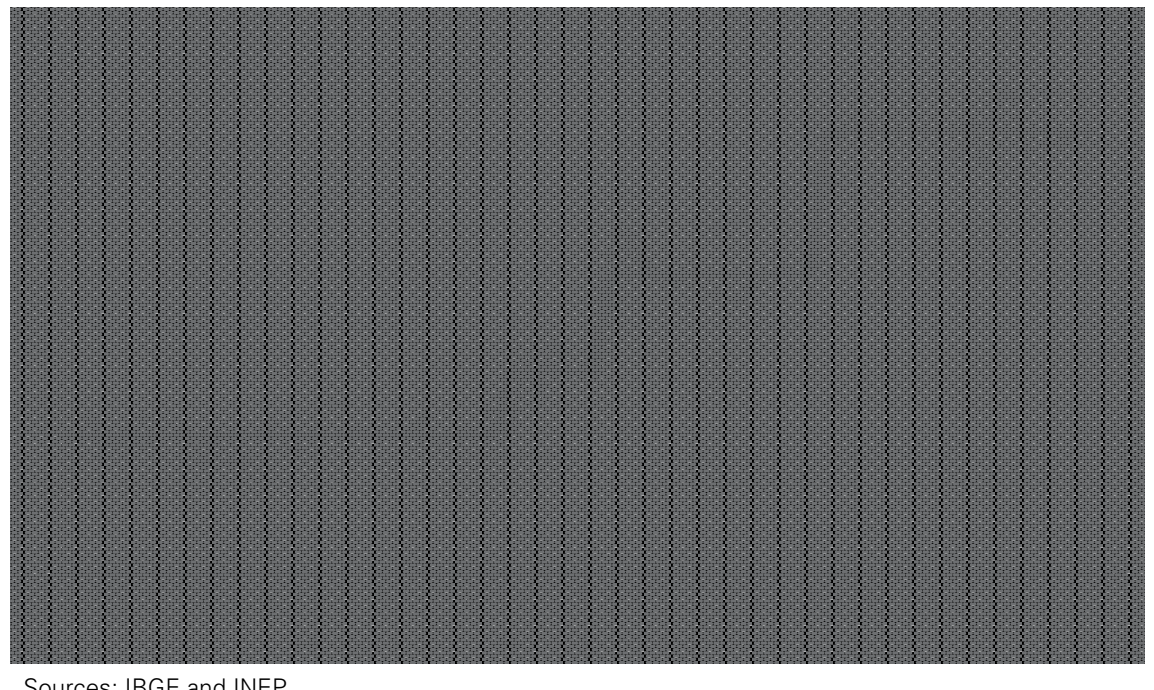

In the case of primary education, the breaks always indicate an increase to a new level of expenditure. The first change was with the First Law of Education. Then, the second increase occurred with the Second Law of Education and the military project of providing a minimum qualification for workers. Finally, after the end of dictatorship there was a new increase in expenditure, which was then enforced by the new Constitution of 1989. It is interesting to note the long period that took the country to start expanding expenditure in primary education, which only happened in 1961. This is related to the lack of political interest during Vargas and the democratic years. The evolution of enrolment follows the break's pattern, with an increase in the long-run. Perhaps a faster increase in expenditure during the initial period, before 1961, would have accelerated the rate of expansion of enrolment rates. 


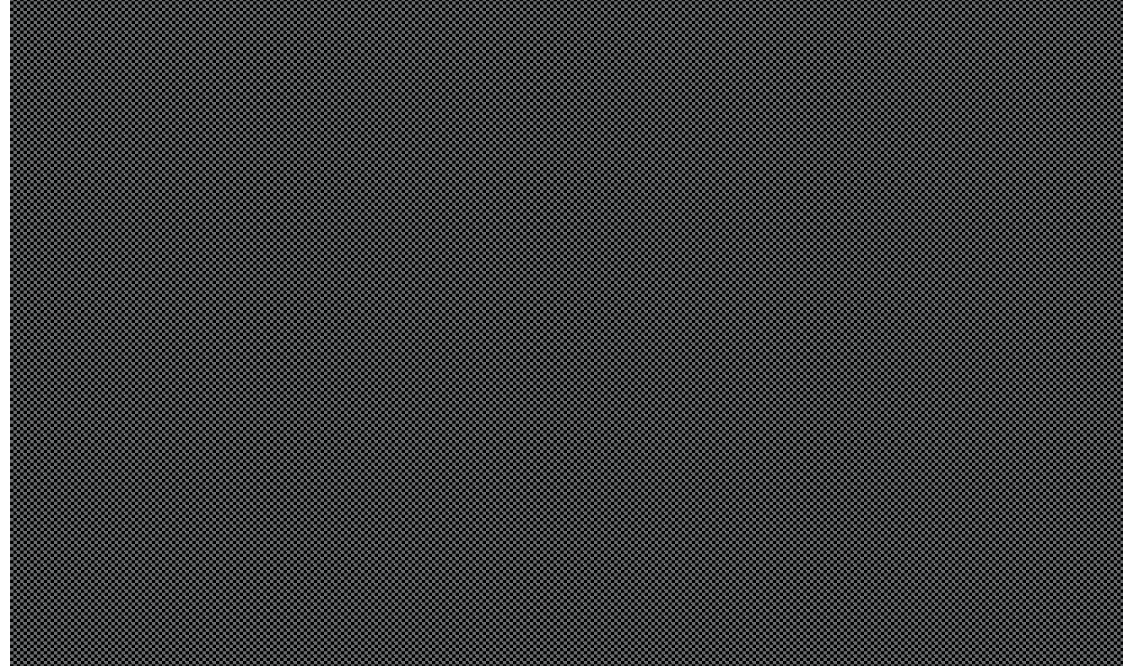

Sources: IBGE and INEP.

The case of secondary education is the shocking one. While there were two initial breaks that increased the expenditure in the end of Vargas and also due to the First Law of Education, there is a strong negative break on the Second Law of Education in 1971. This is related to the already discussed educational policy of the military, which left secondary education behind and favoured higher education. After 1990, expenditure in secondary education started to increase once again with the new Constitution, gaining more fuel with the Third Law. The intriguing situation about this evidence is the impact on enrolment rates. While there was a huge drop on expenditure in 1971, enrolment rates continued to expand. This question would need further analysis, which is out of the scope of this long-run analysis. But based on the data of primary education, it is possible to suggest that enrolment rates continued to expand due to the increase in the number of student finishing primary education at that time. However, while the lack of investment did not prevent the expansion of enrolment, it impacted significantly in its quality, which was strongly reduced. And this created a strong negative path dependence over the quality of secondary education in Brazil (Frankema, 2008; Castro \& Tiezzi, 2004; Wjuniski, 2009). 


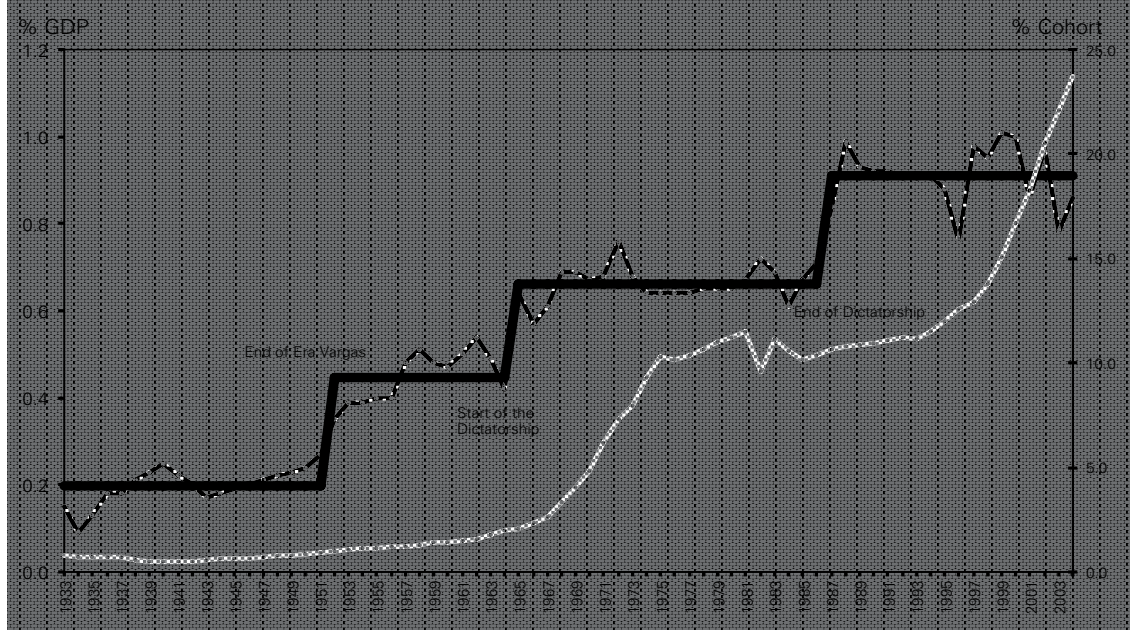

Sources: IBGE and INEP.

The case of tertiary education is the simplest one. As discussed previously, the existence of strong political power in favour of the elites led most governments to invest in higher education. This situation can be clearly seen here. The changes of regimes always led to increases in expenditure in higher education, with breaks occurring in Vargas, a couple of years after the First Law of Education, and also the end of the dictatorship and the Constitution of 1989. The pattern of increasing expenditure created a path dependency of high expenditure in tertiary education.

The results essentially show that there was always a strong increase in expenditure in primary and higher education, while a reduction in expenditure in secondary education. And until 2003, even with the new policies after the Third Law of Education, the level of secondary education expenditure still did not reach the tertiary level. This allocation of resources only benefits a smaller proportion of society which has access to higher public education, with a higher cost per student. The beginning of this situation was already pointed out: the educational policies of the military government in 1971.

\section{CONCLUSIONS}

Today Brazil is considered one of the most important emerging countries. This happens because many institutional, social and economic achievements have been accomplished in the last years: democracy, economic stability and growth, reduction of poverty etc. However, it is clear that the country still needs to improve its human indicators, catching-up to developed levels. The case of education is part of this objective. Education is an end in itself, and deserves more attention in Brazil. 
The objective of this paper was to contribute to this goal, discussing ideas that may help to improve and develop the Brazilian educational system.

By analysing the educational backwardness through a historical perspective, this paper reached the following conclusions. In first place, it argued that political interests really account for a significant part of the lagged situation, with these interests reflecting the different development projects of the country in its distinct periods. Second, it also provided quantitative evidence to support this argument, showing that the political interests can be seen in the light of the allocation of resources between the different levels of education during history. The pattern of structural breaks in the econometric analysis reflected quite well the evolution of the political environment. It was also possible to see, based on the direction of the breaks, the misallocation of public resources between the levels, favoring higher education in the long-run and leaving secondary education behind. Finally, it was possible to see the consequences of these politically-based policies for the Brazilian educational system: (i) by observing how long it took for the country to start investing in all levels of education, a practice that only began in 1961 (ii) by observing the strong level of expenditure in higher education in comparison to the other levels, which created an unequal distribution of education in Brazil that persists today; (iii) and more importantly by demonstrating that the educational policies of the military period created the most significant negative path dependency in Brazilian education. It created underinvestment in secondary education, devaluing its quality, and also leading to a strong inequality between the levels of education (Frankema, 2008; Castro \& Tiezzi, 2004; Wjuniski, 2009).

Based on these contributions, the question that arises is what kind of policy implications can be drawn? What are the changes that are still necessary in Brazilian educational policies? Clearly, based on this discussion, the country needs to find a way to reduce and come to an end with the disequilibrium between the educational levels, with the allocation of resources that still reflect that 1970s. This is the most important conclusion that emerged from the analysis. Two main policy implications come directly from this. First, the country needs to focus and increase investments in secondary education. It is still clearly behind the other levels. Expenditure should increase and a better quality must be targeted. Second, a reduction in higher education expenditure is necessary. There is obviously an over expenditure in this level compared to the others which needs to be restricted. In practical terms, it is very complicated to reduce spending in the already existing public university system. The only possible solution seems to be at least stop increasing it in the long-run. And together with the rise in investments in secondary education, the misallocation may be reduced in the future. This suggestion seems to go completely against the policies that are being adopted by the current government, which is maintaining the pattern of increasing expenditure in higher education. New public universities have been created and the government is also developing a system of subsides to private colleges. It is evident that the present government is trying to correct the gap created by the incorrect policies of the past. They are trying to provide poor students, which come from public secondary schools, a way 
to enter into private universities. But the fact is that this does not appear to be the best option in the long run. Instead, the government should use this money to improve secondary education, in order to develop its quality and in the future allow its students to enter the existing public university system. Only then may the target be transferred to the tertiary system once again. It is important to stress that these conclusions are not going against the existence of free public universities, just arguing that the current situation of Brazilian education is extremely unequal, and by now the target should be on secondary education.

Finally, it is important to point that this is still the beginning of a research agenda for the historical problem of education in Brazil. The literature is incipient and many topics can be clarified and further discussed. It is necessary to disaggregate the expenditure analysis between regions, states, and urban and rural areas. In the same way, it is necessary to discuss regional educational indicators. This may bring new insights on how the allocation of resources influences the education outcomes in the different parts of Brazil. It is also necessary to more deeply discuss each one of these periods, their policies and their consequences. Another important issue that also needs further research is about quality indicators. It is essential to find indicators for the past, and also search for new and better ones for the closer period. All these issues may emerge in the near future research. There is still a long way to fully develop this research agenda, and economic history can have an important contribution to this objective and consequently to the improvement of Brazilian education.

\section{REFERENCES}

Primary Sources:

Constituição Da República Dos Estados Unidos Do Brasil (1934). Presidência da República, Casa Civil, Subchefia para Assuntos Jurídicos. Available at http://www.planalto.gov.br/ccivil_03/Constituicao/ Constitui\%C3\%A7ao34.htm

Lei n. 4.024, Lei de Diretrizes e Bases da Educação Nacional (1961). Presidência da República, Casa Civil, Subchefia para Assuntos Jurídicos. Available at http://www.planalto.gov.br/ccivil_03/LEIS/L4024. htm

Lei N. 5.692, Lei de Diretrizes e Bases da Educação Nacional (1971). Presidência da República, Casa Civil, Subchefia para Assuntos Jurídicos. Available at http://www.planalto.gov.br/ccivil_03/leis/L5692. htm

Lei no 9.394, Lei de Diretrizes e Bases da Educação Nacional (1971). Presidência da República, Casa Civil, Subchefia para Assuntos Jurídicos. Available at http://www.planalto.gov.br/ccivil_03/LEIS/19394. htm

Sources on Quantitative Data:

Instituto Brasileiro de Geografia e Estatística (IBGE) (2003) Estatísticas do Século XX. Rio de Janeiro. Available in CD-Rom

Instituto Nacional de Estudos e Pesquisas Educacionais (INEP). http://www.inep. gov.br/estatisticas

UNESCO — Institute for Statistics. http://stats.uis.unesco.org 


\section{Secondary Literature:}

Abreu, Marcelo de Paiva (ed.) (1990) A Ordem do Progresso: Cem Anos de Política Econômica Republicana 1889-1989. Rio de Janeiro: Editora Elsevier.

Amaral, Luiz Felipe \& Menezes-Filho, Naercio (2009) “As Relações entre Gastos Educacionais e Desempenho Escolar”. Insper Working Paper 164. Available at http://www.insper.org.br/sites/default/files/2009_wpe164_0.pdf. 5 Jun. 2009.

Baer, Werner (2003) A Economia Brasileira. $2^{\text {nd }}$ Edition. São Paulo: Editora Nobel.

Bai, J \& Perron, Pierre (1998) "Estimating and Testing Linear Models with Multiple Structural Changes". Econometrica 66(1): 47-78.

Bai, J \& Perron, Pierre (2003) “Computation and analysis of multiple structural change models” Journal of Applied Econometrics 18:1-22.

Bergés, Ame R (2009) "Vertical and Horizontal inequalities in human capital: Education attainment and Literacy in Latin America during the Twentieth Century". Paper presented at the Mini-Conference A Comparative Approach to Inequality and Development: Latin America and Europe, Fundación Ramón Areces and Instituto Figuerola. Madrid, 8-9. May. 2009.

Bethell, Leslie (ed.) (2005) The Cambridge History of Latin America. Vol IX. Brazil since 1930. Cambridge: Cambridge University Press.

Bomeny, Helena (2008a) “A Educação no Segundo Governo Vargas”. Available at: http://www.cpdoc. fgv.br/nav_gv/htm/3E_ele_voltou/Cenario_educacional.asp. 5 Jun. 2009

Bomeny, Helena (2008b) "Educação e desenvolvimento: o debate nos anos 50". Available at: http:// www.cpdoc.fgv.br/nav_jk/htm/O_Brasil_de_JK/Educacao_e_desenvolvimento_o_debate_nos_ anos_1950.asp. 5 Jun. 2009. 5 Jun. 2009

Bóo, Marcial (2002) "Ideology and Education: Equity and Efficiency" in Abel, Christopher \& Lewis. Colin M (eds.) (2002) Exclusion and Engagement: Social Policy in Latin America. Institute of Latin American Studies, University of London.

Brown, David S (2002) "Authoritarianisms and Education Finance in Brazil". Journal of Latin American Studies 37(1): 115-141.

Carone, Edgar (1980) “A Quarta República (1945-1964)” São Paulo: Difusão Editorial.

Castro, Maria Helena de Magalhães \& Tiezzi, Sergio (2004) “The Reform of Secondary Education and the Implementation of ENEM in Brazil” in Schwartzman, Simon \& Brock, Colin (eds.) (2004) The Challenges of Education in Brazil. Oxford: Symposium Books.

Dourado, Luiz Fernandes (2002) "Reforma do Estado e as Políticas para a Educação no Brasil nos Anos 90". Revista Educação e Sociedade 23(80): 234-252.

Enders, Walter (2004) Applied Econometric Time Series (2 $2^{\text {nd }}$ Edition). New Jersey: Wiley

Fausto, Boris (1994) "Brazil: The Social and Political Structure of the First Republic, 1889-1930" in Bethell, Leslie (ed.) (1994) The Cambridge history of Latin America. Vol.4, c.1870-1930. Cambridge: Cambridge University Press.

Frankema, Ewout (2008) "Comparing the Distribution of Education Across the Developing World, 1960-2005: What Does the Grade Enrollment Distribution Tell about Latin America?" Soc Indic Res 88: 437-455.

Germano, José Willington (2000) Estado Militar e Educação no Brasil (1964-1985). São Paulo: Editora Cortez.

Greene, William H (2008) Econometric Analysis (6 $6^{\text {th }}$ edition). New Jersey: Pearson Prentice Hall.

Havighurst, Robert \& Moreira, J. Roberto (1965) Society and Education in Brazil. Pittsburgh: University of Pittsburg Press.

Hermann, Jennifer (2005) "Reformas, Endividamento Externo e o 'Milagre' Econômico” in Giambiagi, Fabio et al. (eds.) (2005) Economia Brasileira Contemporânea (1945-2004). Rio de Janeiro: Editora Campos.

Kang, Thomas (2009) “Education, Political Power, and Development in Brazil, 1930-1964.” Paper presented at the World Economic History Congress, Utrecht, August.

Lindert, Peter (2009) "Revealing Failures in the History of Education Finance". Paper presented at the 
Mini-Conference A Comparative Approach to Inequality and Development: Latin America and Europe, Fundación Ramón Areces and Instituto Figuerola. Madrid, 8-9. May. 2009.

Maduro, Paulo Rodrigues (2007) Taxas de Matrículas e Gastos em Educação no Brasil. Dissertação de Mestrado, Escola de Pós-Graduação em Economia da FGV, Rio de Janeiro.

Malloy, James (1979) The Politics of Social Security in Brazil. Pittsburgh: University of Pittsburgh Press. Mendonça, Ana Waleska (2000) “A Universidade no Brasil”. Revista Brasileira de Educação No14.

Menezes-Filho, Naercio (2007) Os Determinantes do Desempenho Escolar do Brasil. Instituto Futuro Brasil.

Plank, David N et al. (1996) "Why Brazil Lags Behind in Educational Development" in Birdsall, N \& Sabot, R (1996) Opportuntiy Foregone: Education In Brazil. Inter-American Development Bank. Plank, David N (1996) The Means of Our Salvation: Public Education in Brazil, 1930-95. London: Westview Press.

Rodrik, Dani et al (1995) Getting Interventions Right: How South Korea and Taiwan Grew Rich. Centre for Economic Policy Research. Blackwell.

Schwartzman, Simon (2004) "The Challenges of Education in Brazil” in Schwartzman, Simon \& Brock, Colin (eds.) (2004) The Challenges of Education in Brazil. Oxford: Symposium Books.

Silva, SB (2008) "50 anos em 5: a odisseia desenvolvimentista do Plano de Metas". Available at http:// www.cpdoc.fgv.br/nav_jk/htm/o_brasil_de_jk/50_anos_em_5_o_plano_de_metas.asp. 5 Jun. 2009.

Silva Junior, João dos Reis \& Sguissardi, Valdemar (2005) “A Nova Lei de Educação Superior: Fortalecimento do Setor Público e Regulação do Privado/Mercantil ou Continuidade da Privatização e Mercantilização do Público”. Revista Brasileira de Educação 29: 5-27.

Skidmore, Thomas E (1967) Politics in Brazil, 1930-1964. Oxford: Oxford University Press.

Skidmore, Thomas E (1988) The Politics of Military Rule in Brazil, 1964-1985. Oxford: Oxford University Press.

Wegenast, Tim (2009a) “The Legacy of Landlords: Educational Distribution and Development in a Comparative Perspective”. Comparative Governance and Politics 3(1): 81-107.

Wegenast, Tim (2009b) "Of Latifundia and Coronéis: Agrarian Structure and Educational Inequalities in Brazil”. Paper presented at the Mini-Conference A Comparative Approach to Inequality and Development: Latin America and Europe, Fundación Ramón Areces and Instituto Figuerola. Madrid, 8-9. May. 2009.

Wjuniski, Bernardo (2009) "Education and Development Projects in Brazil (1989-2008): A Political Economy Perspective" Msc in Economic History Dissertation, London School of Economics and Political Science. London. 